\title{
Federalism With and Without Political Centralization:China Versus Russia
}

\section{Citation}

Blanchard, Olivier and Andrei Shleifer. 2001. Federalism With and Without Political

Centralization: China Versus Russia. IMF Staff Papers 48 (S1): 171-179.

\section{Published Version}

$10.2307 / 4621694$

\section{Permanent link}

http://nrs.harvard.edu/urn-3:HUL.InstRepos:30747169

\section{Terms of Use}

This article was downloaded from Harvard University's DASH repository, and is made available under the terms and conditions applicable to Other Posted Material, as set forth at http:// nrs.harvard.edu/urn-3:HUL.InstRepos:dash.current.terms-of-use\#LAA

\section{Share Your Story}

The Harvard community has made this article openly available.

Please share how this access benefits you. Submit a story.

\section{Accessibility}




\title{
FEDERALISM WITH AND WITHOUT POLITICAL CENTRALIZATION: CHINA VERSUS RUSSIA
}

\author{
Olivier Blanchard \\ Andrei Shleifer \\ Working Paper 7616 \\ http://www.nber.org/papers/w7616 \\ NATIONAL BUREAU OF ECONOMIC RESEARCH \\ 1050 Massachusetts Avenue \\ Cambridge, MA 02138 \\ March 2000
}

We thank Stanley Fischer, Alan Gelb, Ed Glaeser, Simon Johnson, Jim Snyder, and Daniel Treisman for comments. We thank the National Science Foundation for financial assistance. The views expressed herein are those of the authors and are not necessarily those of the National Bureau of Economic Research.

(C) 2000 by Olivier Blanchard and Andrei Shleifer. All rights reserved. Short sections of text, not to exceed two paragraphs, may be quoted without explicit permission provided that full credit, including $\mathbb{C}$ notice, is given to the source. 
Federalism with and without Political Centralization: China versus Russia

Olivier Blanchard and Andrei Shleifer

NBER Working Paper No. 7616

March 2000

JEL No. P2, P3, H7, H1

\section{ABSTRACT}

In China, local governments have actively contributed to the growth of new firms. In Russia, local governments have typically stood in the way, be it through taxation, regulation, or corruption.

There appears to be two main reasons behind the behavior of local governments in Russia. First, capture by old firms, leading local governments to protect them from competition by new entrants. Second, competition for rents by local officials, eliminating incentives for new firms to enter.

The question then is why this has not happened in China. We argue that the answer lies in the degree of political centralization present in China, but not in Russia. Transition in China has taken place under the tight control of the communist party. As a result, the central government has been in a strong position both to reward and to punish local administrations, reducing both the risk of local capture and the scope of competition for rents. By contrast, transition in Russia has come with the emergence of a partly dysfunctional democracy. The central government has been neither strong enough to impose its views, nor strong enough to set clear rules about the sharing of the proceeds of growth. As a result, local governments have had few incentives either to resist capture or to rein in competition for rents.

Based on the experience of China, a number of researchers have argued that federalism could play a central role in development. We agree, but with an important caveat. We believe the experience of Russia indicates that another ingredient is crucial, namely political centralization.

Olivier Blanchard

Department of Economics

MIT, E52-373

Cambridge, MA 02139

and NBER

blanchar@mit.edu
Andrei Shleifer

Department of Economics

Littauer Center M-9

Harvard University

Cambridge, MA 02138

and NBER

ashleifer@harvard.edu 
Over the last decade, China's GDP has grown at one of the highest rates in the world, Russia's at one of the lowest. The difference has come mostly from the growth of the new private sector. In China, the new private sector has thrived. In Russia, it has stagnated.

Why this sharp difference between private sector evolutions? In both countries, the evidence points to the importance of the behavior of local governments. In China, local governments have actively contributed to the growth of new firms (Oi [1992], Qian and Weingast [1997].) In Russia, local governments have typically stood in the way, be it through taxation, regulation, or corruption (Shleifer [1997], Johnson et al. [1997], McKinsey [1999], and EBRD [1999]. $)^{1}$

There are two main hypotheses for the attitudes of local governments in Russia:

The first, call it "capture", is that local governments have been captured by the initial rent holders, primarily by the old firms which dominated the Russian economy before the transition. In that view, local governments have worked both to generate transfers to these firms, and to protect them from competition by new firms. In this first view, their hostile attitude vis a vis the new private sector has been deliberate.

The second view, call it "competition for rents", is that their behavior has been instead the unintended result of administrative disorganization. Too many agencies have tried to extract rents from new private firms, making it unprofitable to create or run a private business, at least legally. ${ }^{2}$

\footnotetext{
${ }^{1}$ The McKinsey study of ten sectors of the Russian economy, and of the specific obstacles faced by new firms in each sector, is particularly instructive in this regard.

${ }^{2}$ Shleifer and Vishny [1993] have shown how such disorganization and competition for rents leads to a much worse outcome than monopoly corruption from an organized government. Based on a survey of shops in Russia and Poland, Frye and Shleifer [1997] have shown shops in Moscow are visited by a much larger number of inspectors and
} 
These two lines of explanation are plausible, and not mutually exclusive. But they raise the obvious question of why things have been different in China. Here again, there are two main hypotheses:

The first is that the initial rent holders were weaker in China than in Russia. China started its transition from a very low level of economic development. Its agriculture did not rely on large collective farms, and its industry had relatively few large entreprises. Russia, in contrast, started its transition as a fully industrialized economy, dominated by large state firms and collective farms. According to this view, the potential for capture was simply more limited in China than in Russia.

The second points to the strength of the central government in China. Transition in China has taken place under the tight control of the communist party: As a result, the central government has been in a strong position both to reward or to punish local administrations, reducing both the risk of local capture or the scope of competition for rents. By contrast, transition in Russia has come with the emergence of a partly dysfunctional democracy. The central government has been neither strong enough to impose its views, nor strong enough to set clear rules about the sharing of the proceeds of growth (Treisman [1999a], Shleifer and Treisman [1999]). As a result, local governments have had few incentives either to resist capture or to rein in competition for rents (Treisman [1999b]).

The aim of this paper is to explore this last argument, and more generally to explore the role of federalism in transition. The question is an important one: Based on the experience of China, a number of researchers have argued that federalism could play a central role in development (see in particular Qian and Weingast [1997], Roland [1999].) Indeed, a new term, "market preserving federalism" has been coined to emphasize the benefits of decentralization for Chinese growth. We agree, but with an important 
caveat. We believe the experience of Russia indicates that another ingredient is crucial, namely political centralization. In doing so, we echo a theme first developed by Riker [1964]: For federalism to function and to endure, it must come with political centralization.

\section{A model of federalism and incentives.}

We start by writing down a model of federalism and local government incentives. The model is very simple, but it provides a convenient way to look at the facts and discuss the issues. This is what we do in the next two sections.

Think of the government as having two levels, central, and local (in other words, ignore for the moment the fact that there are at least three relevant levels of government in both Russia and China: central, regional and local).

Suppose each local government faces a simple choice. It can either foster growth, by limiting transfers of resources to state and former state firms and allowing new private firms to enter and to grow. Or it can kill growth, by transfering resources to old firms and/or preventing new firms from being created.

Why might a local government choose the second option? Under the "capture" view, it may want to protect state or ex-state firms from competition: Under the "competition for rents" view, it may be simply unable to prevent bribes and corruption by local officials. Sorting out the relative importance of the two should be high on the research agenda, but is not essential here. For our purposes, both have the same implication: no growth.

Let $y$ be the additional output under growth. With appropriate normalization, let $y$ also stand for the additional amount of revenues available to the central and local governments under growth. Let $b$ be the private benefits to the local government of killing growth. Under the capture interpretation, 
$b$ may reflect the transfers back from existing firms to the local government, in the form of bribes, cash or in-kind payments. Under the competition for rents interpretation, $b$ may reflect the cost to a local government of reducing or coordinating bribe taking by local officials.

Now turn to the central government. Assume (an assumption to which we return later) that the central government wants to foster growth. And think of the central government as having two main tools, a carrot and a stick:

- Revenue sharing (the carrot): The central government can choose the extent of revenue sharing with local governments. Let $a$ be the share of revenues from additional growth going to local governments: If a local government chooses to foster growth, it gets ay in revenues. Presumably, how much the local government values growth is proportional to ay. By appropriate normalization, denote it also by ay.

It is important to distinguish between ex-ante and ex-post $a$. If the central and the regional governments can commit to a tax sharing schedule (net of transfers from the center back to the regions), the two will of course be the same. But if they cannot, for instance because the central government is broke and desperately needs funds to keep down its deficit, ex-ante $a$ may be well higher than the ex-post $a$. The one which is relevant to regional governments' decisions is obviously ex-post $a$. We shall return to this issue below.

- Political centralization (the stick): The central government can affect the probability that the local government stays in power to enjoy either the revenues from growth or the private benefits from killing growth. Denote by $p_{x}$ the probability that the local government stays in power if it kills growth, and by $p_{y}$ the corresponding probability if it fosters growth. Define $p=p_{y} / p_{x}$. The value of $p$ clearly depends first on 
whether local officials are appointed or elected. If they are appointed, then presumably the central government can choose $p$ freely and make it as high as it wants. If they are elected, the outcome depends on the ability of the central government to affect the outcome of the election, through endorsement and support of specific candidates. If, for example, the center has little control over the outcome; and capture is important, $p$ may be less than one: The local government may be more likely to be reelected if it kills growth than if it fosters it.

Under these assumptions, the local government chooses growth if $p_{y} a y>p_{x} b$, or equivalently if:

$$
p a y>b
$$

The local government is more likely to choose growth, the stronger the stick (the higher $p$ ), the larger the carrot (the higher $a$ ), the larger the growth potential (the higher $y$ ), and the smaller the benefits of capture or the lower the costs of reining in competition for rents (the lower $b$ ). This formula provides a convenient way of organizing the discussion of Russia versus China.

\section{Growth, tax sharing, political centralization, and other issues.}

Before proceeding to look at the empirical evidence on the various parameters of the model, one may well want to challenge one of the main assumptions of the model, namely that the central government is pro-growth, or at least more pro-growth than local governments. Surely, both China and Russia provide numerous examples where the policies of the central government destroyed the economy. However, in the context of transition and change, the assumption that the central government is less likely to be captured by 
initial rent holders than local governments seems reasonable. Local governments are smaller relative to state and ex-state firms, more directly affected by the unemployment implications of the closing of a particular firm, more likely to respond favorably to requests for transfers or protection. Central governments may well be captured as well, but not necessarily. by groups opposed to growth. Capture by the "oligarchs" for example may well lead to a massive redistribution of wealth in their favor, but not necessarily to lower growth.

(1) Much previous research has focused on $y$. If growth prospects are very good, then letting new firms enter and fostering growth is attractive. The example of Moscow, and of its mayor, Luzhkov, comes to mind here. But if growth prospects are dim anyway, the returns to allowing new business to enter and grow as opposed to protecting the old firms may be low, and $y$ may be small. This is particularly likely if the improvements from pro-growth policies take a long time to materialize, and the incumbent politicians are unlikely to benefit from them.

If $y$ is small, there may be very little the center can do to convince local governments to choose growth. Even large values of $a$ and $p$ may not change the inequality.

(2) Turning to the first of the two parameters which reflect the structure of federalism, a number of recent studies have provided some evidence on $a$, both for Russia and for China. ${ }^{3}$ In describing the evidence, we need to distinguish between the three levels of government, central, regional and local.

\footnotetext{
${ }^{3}$ There are enough differences between the specific regressions run in the Russian and Chinese studies that the comparison should be taken as preliminary at this point. As crude as it is however, it points to a substantial difference between the two countries.
} 
In an econometric study of the fiscal relations between Russia's local and regional governments, Zhuravskaya [2000] has found that marginal $a$ is only about 0.1 , giving local governments only weak incentives to increase the tax base. No corresponding study exists for the relations between Russia's regional and central government. Based on informal evidence, marginal $a$ appears higher, but not very. high.

In an econometric study of the fiscal relations between China's regional and central governments, Jin et al. [1999] have found a high value of marginal $a$, about 0.8 . Importantly, they have also found that the ex-post value of $a$ appears very similar to the ex-ante $a$ (i.e $a$ as implied by the explicit sharing rules). In other words, the central government does not appear to expropriate the regions after the fact in the event their tax revenues are unusually high. No corresponding study exists for the relations between China's local and regional governments. Wong [1997] suggests that the nature of the contracts between local and regional governments, and therefore the outcomes, may be similar to those for the relation between central and regional governments.

The evidence therefore suggests that $a$ is lower in Russia than in China. Why might this be the case? One reason may be that, since 1995 (when it started a stabilization program), the central government in Russia has been continuously broke, and consequently eager to renegotiate its tax agreements with regions (attempting to reduce ex-post a relative to ex-ante $a$ ). Such renegotiation is particularly easy for the central government in Russia because it returns a significant share of its tax revenues back to the regions, and hence has the ability to default on its promised transfers. ${ }^{4}$ Another rea-

\footnotetext{
${ }^{4}$ The notion that a fiscal crisis may lead to a low ex-post $a$ is suggestive of the scope for multiple equilibria: Central governments in financial trouble cannot commit to sharing revenues, leading to anti-growth policies by local governments, which in turn kill growth, making the fiscal situation worse.
} 
son may be that, given the very low $p$ in Russia, there was simply no value of $a$ in Russia which would have made local governments choose growth. This takes us to the discussion of differences in $p$ between the two countries.

(3) In China, the Communist Party has the power to appoint and fire governors, and has exercised this power both to support the governors whose regions have performed well economically and to discipline governors who have followed anti-growth policies. Perhaps as an ultimate prize, the governors whose regions perform well have been brought into the national government in Beijing. It is clear that, in China, $p$ is a large number -if the power of the Communist Party is viewed as absolute, then $p$ is close to infinity.

In Russia, governors are now elected, not appointed. And the ability of the national government to reward or penalize governors through administrative and electoral support has been limited. For this reason, $p$ in Russia is much lower than in China; it is arguably below 1 .

This difference in political control, rather than the difference in revenue sharing arrangements, may be the reason why inequality ( 1 ) holds for China and not for Russia. For a high enough $p$, even a low a may sustain pro-growth policies. The Chinese central government has allowed a substantial share of tax revenues, as well as spending responsibilities, to stay with the regions, but given its power of appointment, it might have gotten away with greater centralization of spending. For the Russian government on the other hand, there may no value of $a$ that would lead local governments to foster growth. As a result, there may have been little incentive for the central government to maintain a high value of $a$.

It is interesting to look at the evolution of the relation between central and regional governments in Russia in the 1990s in the light of this model. In the early 1990s, Russia's central government relied on the use of $a>1$ for most of the regions. It did this by taxing a few oil-producing regions, and by using deficit finance to compensate for the resulting lack of net revenues at 
the center (Treisman [1999a]). During that period, particularly in 1992-1993, Yeltsin also had administrative control over the governors, so $p$ was higher than afterwards. As Treisman [1999a] shows, this policy worked tolerably. well for a while, and bought the center peace with the regions.

In the mid to late 1990s, that equilibrium fell apart. First, stabilization policies forced the central government to reduce $a$ for most regions, as the central deficit had to be reduced and hence large transfers to the oblasts became unaffordable. Second, political decentralization and party-free gubernatorial elections reduced $p$ significantly. Third, the continued recession reduced at least the expectation of $y$. In Russia's federal structure today, equation (1) fails, because both $p$ and $a$ are low. As we just argued, the key factor may be the low value of $p$, rather than the low value of $a$. To return to Riker, the peripheralized federalism which characterizes today's Russia may simply not be sustainable.

Our focus on the role of political parties in Russia in achieving-or not achieving-political centralization may be too narrow. In Russia, two forces have become at least partial substitutes. The first is the national media. Media companies in Russia are private, and controlled by interests closely tied to political movements, particularly the government and the centerleft opposition. The media groups have used television and newspapers aggressively to get their preferred candidates elected in the 1996 Presidential election (when both supported Yeltsin) and especially in the 1999 Duma elections. The second centralizing force has been the energy monopolies, especially Gazprom and United Energy Systems. The first holds monopoly over the supply of gas in Russia; the second controls the electricity grid. Both companies, while nominally private, have been close to the government. Both have been used by the government to provide cheap energy, as well as energy without payment, to cooperative regions. In this way, both have been used to make the conduct of regional governments more responsive to the needs of the center. How efficient or desirable these substitutes have 
been is however an open question.

\section{Discussion and implications.}

Our analysis has a number of implications, for China, for Russia, and for the economic theory of federalism.

With respect to China, our analysis implies that to the extent that federalism has played a helpful role in promoting China's economic growth, such federalism relied crucially on the centralizing role of the Communist Party. ${ }^{5}$ If the Communist Party, as it yields power in the future, is not replaced or supplemented by other national parties which influence the appointment or the election prospects of governors, $p$ will fall, leading to greater rentseeking and lower efficiency in its federal arrangements. The message of our analysis for China is clear: The competitive benefits of "market-preserving federalism" emphasized by China scholars depend very much on political centralization.

With respect to Russia, our analysis suggests that federalism has failed precisely because of political decentralization. There is no question that carefully designed tax and other fiscal policies can raise $a$ in Russia. These policies would require a clearer division of tax bases between the central and the regional governments, as well as a division of tax collection and spending responsibilities that does not exist today. ${ }^{6}$ Nevertheless, given the low level of political centralization, such fiscal measures may not be enough to induce local governments to foster growth.

\footnotetext{
${ }^{5}$ Even in China, control by the center is not absolute. Young [2000] argues, for example, that political centralization has not prevented regional governments from erecting trade barriers between provinces.

${ }^{6}$ See Shleifer and Treisman [1999] for one such proposal.
} 
Will centralization come, and if so what form will it take? In principle, centralization in Russia could come through the creation of national parties which exercise influence over the governors needing their support in elections. Centralization may alternatively take the form of greater administrative control over governors through more aggressive bargaining over issues that bear on their regions and remain under the control of the center, such as the allocation of electricity and gas. Centralization may also involve the suspension of the democratic process. Presumably, a turn to a competitive national party system is more compatible with political freedom than are the alternatives. Yet some form of centralization is probably necessary for the federal equilibrium in Russia to change-for a switch in the sign of inequality (1).

From this perspective, Mexico provides a very instructive, though not in every way appealing, example. In the 1920s and 1930s, the Mexican economy presented a far more extreme version of peripheralized federalism than Russia presents today (Diaz-Cayeros [1997]). Following the revolution, the Mexican states were each run by their own dictator, or cacique, who controlled the regional sources of military power, collected the regional taxes without remitting them to the center, and erected trade and other barriers against other Mexican states. The result was fiscal disorder and economic stagnation. In 1938, President Calles, with the support of the military, transformed the PRI into a national hegemonic party. He convinced the regional leaders to join the party and to adhere to its national policies with an offer of a carrot and a stick. The carrot was a promise of long, secure, and profitable careers under the protective wing of the PRI, which would gain control over the nomination (and effectively the election) of governors. The stick was a threat of personal violence against the caciques who declined to join. Nearly all joined, a few who did not were killed. As part of this deal, the central government obtained full centralized control over tax collection in Mexico, leaving the states to rely on transfers from the center, as well as 
control over trade and regulatory policies that turned Mexico into a common. market. The economic benefits of the 1938 arrangement were large, but they did come with tremendous political centralization. It may have been "market-preserving federalism," but the political market was not the one that was preserved.

The last example leads us to the implication of our analysis for federalism in general. This implication is not new, and draws on Riker [1964], yet it has been neglected in the recent discussions of China praising the decentralization benefits of federalism. As best we can tell, the economic benefits of decentralization obtained from federalism rely crucially on some form of political centralization. Without such centralization, the incentives to pursue regionalist policies are too high, and cannot be eliminated solely through clever economic and fiscal arrangements. It is possible that a federal country can muddle through without political centralization, as Russia has done in the 1990s and Brazil and India have done for longer, but some political system of aligning the interests of national and regional politicians is needed to get beyond muddling through. 


\section{References}

Diaz-Cayeros; A., 1997, Political responses to regional inequality. Taxation and distribution in Mexico., Unpublished Ph.D. dissertation, Duke University.

European Bank for Reconstruction and Development, 1999, Transition Report 1999; Ten years of transition, London, U.K.: EBRD.

Frye, T. and Shleifer, A., 1997, The invisible hand and the grabbing hand, American Economic Review, Papers and Proceedings 87(2), 354-358.

Jin, H., Qian, Y., and Weingast, B., 1999, Regional decentralization and fiscal incentives: Federalism, Chinese style, mimeo, presented at the Nobel Symposium on Transition, September.

Johnson, S., Kaufmann, D., and Shleifer, A., 1997, The unofficial economy in transition, Brookings Papers on Economic Activity 2, 157-240.

McKinsey Global Institute, 1999, Russia's economic performance, Moscow: McKinsey.

Oi, J., 1992, Fiscal reform and the economic foundations of local state corporatism in China, 45, 99-126.

Qian, Y. and Weingast, B., 1997, Federalism as a commitment to preserving market incentives, Joumal of Economic Perspectives 11, 83-92.

Riker, W., 1964, Federalism: Origins, Operation, Significance., Little, Brown and Co, Boston, MA.

Roland, G., 1999, Politics, Markets, and Firms: Transition and Economics, MIT Press, Cambridge, MA, forthcoming.

Shleifer, A., 1997, Schumpeter lecture: Government in transition, European Economic Review 41, 385-410.

Shleifer, A. and Treisman, D., 1999, Without a Map: Political Tactics and Economic Reform in Russia, MIT Press, Cambridge MA. 
Shleifer, A. and Vishny, R., 1993, Corruption, Quarterly Journal of Economics pp. $599-617$.

Treisman, D., 1999a, After the Deluge, University of Michigan Press, Ann Arbor, MI.

Treisman, D., 1999b, Tax evasion and regional "fiscal protection" in federal states: A model with evidence from Russia., mimeo, UCLA.

Wong, C., 1997, Financing Local Government in the People's Republic of China, Oxford University Press, Hong Kong.

Young, A., 2000, The razor's edge: Distortions, incremental reform and the theory of the second best in the People's Republic of China, Quarterly Journal of Eonomics, forthcoming.

Zhuravskaya, E., 2000, Incentives to provide local public goods. fiscal federalism, Russian style, Journal of Public Economics, forthcoming. 